\title{
横浜市周辺の公共建築物と一般住宅における 室内環境中化学物質濃度
}

\author{
田中 礼子1,2), 内山 茂久 ${ }^{2)}$, 稲葉 洋平 ${ }^{2)}$, 欅田 尚樹2) \\ 1) 横浜市衛生研究所（ ₹ 236-0051 神奈川県横浜市金沢区富岡東2-7-1） \\ 2) 国立保健医療科学院（=351-0197 埼玉県和光市南2-3-6)
}

[平成27年11月 2 日受付, 平成28年 1 月 12 日受理］

\section{Indoor Air Quality of Institutional Buildings and Residential Houses in Yokohama}

\author{
Reiko TANAKA ${ }^{1,2)}$, Shigehisa UCHIYAMA ${ }^{2)}$, Yohei INABA $^{2)}$ and Naoki KUNUGITA ${ }^{2)}$ \\ ${ }^{1)}$ Yokohama City Institute of Public Health \\ (2-7-1 Tomiokahigashi, Kanazawa, Yokohama, Kanagawa 236-0051) \\ ${ }^{2)}$ National Institute of Public Health \\ (2-3-6 Minami, Wako, Saitama 351-0197)
}

[Received November 2, 2015; Accepted January 12, 2016]

\begin{abstract}
Summary
Indoor air quality is a significant concern, because when the hours spent sleeping, working in offices or at school are added up, people on average spend the vast majority of their time indoors where they are repeatedly exposed to indoor air pollutants. In this study, gaseous chemical compounds in institutional and residential buildings were measured in order to evaluate chemical exposure to office worker. Gaseous chemical compounds were measured in indoor and outdoor air of 18 institutional buildings and 77 residential houses throughout Yokohama in winter and summer. Four kinds of diffusive samplers were used in this study: DSD-BPE/DNPH packed with 2,4-dinitrophenylhydrazine and trans-1,2-bis (2-pyridyl) ethylene coated silica for ozone and carbonyls; VOC-SD packed with Carboxen 564 particles for volatile organic compounds; DSD-TEA packed with triethanolamine impregnated silica for acid gases; and DSD-NH $\mathrm{N}_{3}$ packed with phosphoric acid impregnated silica for basic gases. As results of this study, there were no institutional buildings exceeding Ministry of Health, Labour and Welfare, Japan (MHLW) guidelines in winter and summer. However, in residential houses, 19\% houses in summer and 15\% houses in winter exceeded guidelines by MHLW. Total gaseous chemical compounds of institutional buildings is about half of residential houses in both summer and winter. Almost all compounds in residential indoor air were present at higher levels in summer than in winter. However, the nitrogen dioxide concentrations in residential indoor air particularly increased only during winter and was well correlated with the formic acid concentration (correlation coefficient=0.958).
\end{abstract}

Key words: indoor air quality, institutional buildings, diffusive sampler

\section{1.はじめに}

室内環境中の化学物質の中には, 厚生労働省による室内濃度指針 值等が定められているものを含め多様な物質が存在する。室内空気 質は建築物の種類や用途, 室内の建材や什器等の使用状況などによ り異なる。したがって, 居住空間の安全性確保のためには, 様々な 室内環境に存在する化学物質を総合的に把握する必要がある。都会 に居住する人は一日の中で $90 \%$ の時間を住宅や公共建築物などの室 内環境で過ごし1)，60\%の時間を自宅で過ごしている2)という報告 もあり, 人の生活サイクルの中で自宅は長時間を過ごす代表的な居 住空間である。また, 勤労者にとっては, 職種などにもよるが職場
も自宅同様に代表的な居住空間となっていることが多い。その他， 不特定多数の人が日中に利用する居住空間のひとつに公共建築物が あげられる。公共建築物で日中を過ごすのは施設の利用者だけでな く, そこで働いている人もいるため, 公共建築物には職場としての 側面もある。しかし, 自宅と公共建築物とでは室内の建材や什器等 以外に広さや空調設備等も異なっており, 室内空気質にも相違があ ることが予想される。異なる空気環境が人に及ぼす影響を総合的に 把握するためには, 自宅, 職場, 屋外などのそれぞれの場所の空気 環境の調査を併せて行う必要がある。

日本国内に扔ける一般住宅の室内環境については, $2000 ２ 004$ 年に冬季を中心とした全国調査 ${ }^{3)}$ が，また2011～2014年には夏季 
と冬季における全国調査 ${ }^{4}$, 5) が実施され, 詳細な室内空気質の把握 がなされている。しかし，人が自宅と同様に長時間を過ごす公共建 築物に焦点を当てた報告は少なく, 1〜2施設を対象としたスポッ 卜的な調查報告 ${ }^{6}$ が行われているのみである。さらに，公共建築物 と一般住宅の室内空気質を同時期に調査し，比較した報告はない。

空気中の化学物質濃度の測定方法としては, 拡散サンプラー 法7-10) とアクティブサンプリング法 ${ }^{11}$ の 2 種類の方法がある。拡散 サンプラーは, 小型軽量でサンプリング用のポンプを必要としない ため, 場所を選ばず, 操作が簡便で, 騒音がないという特徵がある。 また，郵送で送付・回収ができるため，同時期に多地点で調査する ことが可能である。

本研究では, オゾン, アルデヒド類, ケトン類, ギ酸, 酢酸, 二 酸化窒素, 二酸化硫黄, アンモニア, 揮発性有機化合物 (VOCs) を捕集することができる 4 種の拡散サンプラーを用いることで，広 範囲に及ぶ化学物質に関し, 横浜市内の 18 公共建築物の屋内・屋外 にて，夏季・冬季の 2 回にわたる一斉調査を単年で行った。また， これと併せて横浜市およびその周辺地域にある一般住宅77戸の屋 内・屋外に扔いても同時期に同様の測定を行った。そして, これら により同一地域における公共建築物と一般住宅という異なる空気環 境中の化学物質の夏季抢よび冬季における実態を調査し, これらの 比較を行うとともに，都市部に居住する人をとりまく空気環境につ いて検討を行った。

\section{2. 方法}

\section{1 調査期間および調査対象施設}

夏季（2012年 7 ～9 月初旬）および冬季（2012年12月～2013年 3 月）に計 95 棟の公共建築物あるいは一般住宅において空気環境実 態調査を行った。

公共建築物に抢ける調査は，横浜市内にある公共建築物18施設に 扔いて行った。調査対象とした施設は全て特定建築物に該当する大 規模施設，かつ，不特定多数の市民が利用する用途の施設を横浜市 内18区のほほ全域から 1 または 2 施設ずつ選定し，各施設の事務フ ロアおよび屋外において測定を実施した。調査した公共建築物の場 所を Fig. 1に示す。

一般住宅における調查は，横浜市およびその周辺地域にある個人 が居住する住宅77戸を調査対象として，一般住宅の屋内，屋外にお いて測定を実施した。

\section{2 調查方法}

測定箇所に 4 種類の拡散サンプラーを設置して 24 時間の測定を行 い, 計55物質の空気環境中化学物質濃度の測定を行った。また, 住 宅の種類や築年数, 冷暖房器具の使用状況などの調査対象施設およ び測定箇所の状況に関してはアンケートにより調査を行った。

\section{2. 1 調査に用いた拡散サンプラーと測定対象物質 DSD-BPE/DNPH}

原理：空気中のアルデヒド類は，2,4-ジニトロフェニルヒドラジ ン（DNPH）と反応してヒドラゾン誘導体を生成する。また，オゾ ンは trans-1,2-ビス (2-ピリジル) エチレン（BPE）と反応してピ リジン-2-アルデヒド（2PA）を生成し12,13)，この2PAが DNPH と 反応しヒドラゾン誘導体を生成する。これらの誘導体を HPLCで 分析することで，オゾンとカルボニル化合物の同時測定が可能に なる9)。また，DNPH 及びアルデヒドのヒドラゾン誘導体はオゾン で破壊されることが報告14-16) されているが，DNPH と共に含まれる BPE はオゾンスクラバーとしても働き，オゾンによるヒドラゾン 誘導体の破壊を防ぐことができる。
作製方法：シリカゲル100 g を水, メタノール，アセトニトリル でよく洗浄した後, BPE $(7 \mathrm{~g})$, DNPH 塩酸塩 $(1 \mathrm{~g})$, リン酸 $(1.2$ $\mathrm{mL})$ を添加した。その後, ロータリーエバポレーター $\left(40^{\circ} \mathrm{C}\right)$ を 用いて減圧乾固させ, 密封容器に保存した。この BPE/DNPH 含 浸シリカゲル270 mg を, 空の拡散サンプラーDiffusive Sampling Device（DSD）に充填し DSD-BPE/DNPH とした。

分析方法：ジメチルスルホキシド/アセトニトリル (25/75) 混 合溶液 $5 \mathrm{~mL}$ で DSD-BPE/DNPH を溶出し, HPLC で分析した。こ の際，DNPH 誘導体の異性化 ${ }^{17-19)}$ を考慮し，これらの標準溶液にリ ン酸を $0.1 \%$ 添加して異性体比を一定にした後, 分析を行った。オ ゾンの他，21成分のカルボニル化合物が定量可能である。

\section{DSD-TEA}

原理 : 大気中の二酸化窒素, 二酸化硫黄, 塩化水素, カルボン酸 などの酸性ガスは, トリエタノールアミン (TEA) と反応して対応 する陰イオンを生成する。この各種陰イオンをICで分析すること により，酸性ガスを定性，定量することができる。

作製方法: シリカゲル $100 \mathrm{~g}$ を純水, アセトニトリルでよく洗浄 した後, TEAを $10 \mathrm{~mL}$ 添加した。その後, ロータリーエバポレーター $\left(40^{\circ} \mathrm{C}\right)$ を用いて減圧乾固させ, 密封容器に保存した。このTEA含 浸シリカゲル250 mg を空の DSD に充填し DSD-TEA とした。

分析方法：純水 $5 \mathrm{~mL}$ で DSD-TEA を溶出し，ICで分析した。

\section{DSD- $\mathrm{NH}_{3}$}

原理：大気中のアンモニアやトリメチルアミンなどの塩基性ガス は, リン酸と反応して対応する陽イオンを生成する。この陽イオン をICで分析することにより, アンモニアを定性, 定量することが できる。

作製方法: シリカゲル $100 \mathrm{~g}$ を純水, アセトニトリルでよく洗浄 した後,リン酸を $5 \mathrm{~mL}$ 添加した。その後, 窒素ガス雲囲気中でロー タリーエバポレーター $\left(40^{\circ} \mathrm{C}\right)$ を用いて減圧乾固させ, 密封容器に

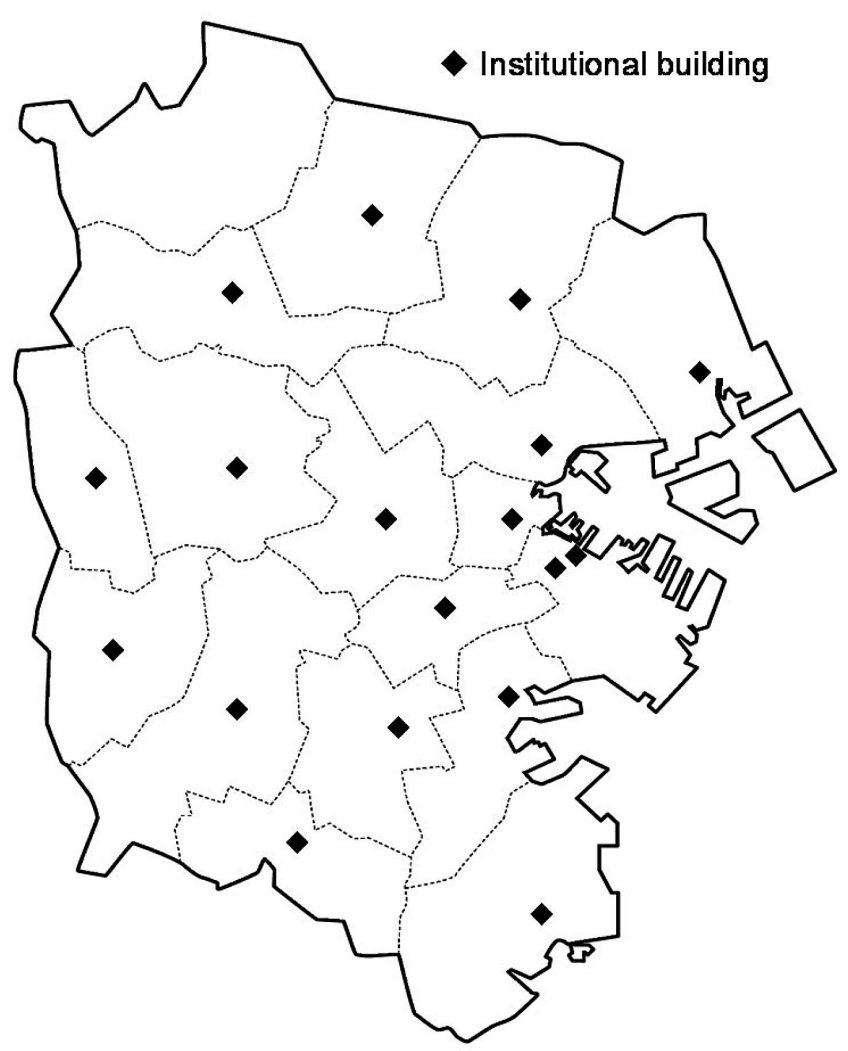

Fig. 1 Location of institutional buildings in Yokohama City 
保存した。このリン酸含浸シリカゲル $250 \mathrm{mg}$ を空の DSD に充填し DSD-NH とした $^{10)}$ 。DSD-NH3 ${ }_{3}$ アアルミ製保存袋に入れ密閉した。 分析方法：純水 $5 \mathrm{~mL}$ で DSD-NH 3 を溶出し， IC で分析した。

\section{VOC-SD}

原理：大気中の VOCs は，炭素系吸着剤（カーボンモレキュラー シーブス）に物理的に吸着する。吸着したVOCs を GC/MS で分析 することにより，VOCs を定性，定量することができる。

分析方法：サンプラー内の吸着剤をバイアルに移し，二硫化炭素 $1 \mathrm{~mL}$ ，内部標準液（10 $\mu \mathrm{g} / \mathrm{mL}$ ベンゼン $-d 6$ メタノール溶液） $10 \mu \mathrm{L}$ を加え振とうし，GC/MSで分析した。検量線には市販の VOCs 混 合標準液 (関東化学製, 45 成分, $1 \mathrm{mg} / \mathrm{mL}$ ) を用い, $0.1,0.2,0.3,0.4,0.5$ $\mathrm{mg} / \mathrm{L}$ に調製した標準溶液を使用した。なお，TVOC 濃度は定量し たこれら VOCs 濃度を合計して求めた。

\section{2 . 2 温湿度測定}

測定期間中の屋内の温湿度は，おんどとり（TR-72Ui，T\&D 社製） を用いて10分間隔で記録した。屋外の温湿度については，測定期間 中のアメダス (気象庁) 横浜のデータを用いた。

\section{3. 結果と考察}

\section{1 ガス状化学物質濃度}

公共建築物㧍よび一般住宅における屋内と屋外の代表的な化学物 質の濃度（算術平均值，中央值，最大值）について，夏季の值を Table 1に, 冬季の值を Table 2に示す。

厚生労働省は室内濃度指針值（以下，指針值）を, ホルムアルデ ヒド $\left(100 \mu \mathrm{g} / \mathrm{m}^{3}\right)$ ，アセトアルデヒド $\left(48 \mu \mathrm{g} / \mathrm{m}^{3}\right)$ ，トルエン $(260$ $\left.\mu \mathrm{g} / \mathrm{m}^{3}\right)$, キシレン $\left(870 \mu \mathrm{g} / \mathrm{m}^{3}\right)$, エチルベンゼン $\left(3800 \mu \mathrm{g} / \mathrm{m}^{3}\right)$, パラジクロロベンゼン $\left(240 \mu \mathrm{g} / \mathrm{m}^{3}\right)$, 暫定目標值として TVOC (400 $\left.\mu \mathrm{g} / \mathrm{m}^{3}\right)$ ，暫定指針值案としてノナナール $\left(41 \mu \mathrm{g} / \mathrm{m}^{3}\right)$ を策定して いる。これらの室内濃度指針值掞よび暫定目標值，並びに暫定指針 值案(以下, 指針值等) と本調査に扔ける測定結果との比較を行った。

公共建築物18施設に打いては, 夏季抒よび冬季の屋内・屋外とも 調査対象とした化学物質の中では指針值等を超過した物質はなく， 室内空気質は良好であると考えられた。

本調査対象の公共建築物は全て, 建築物に扔ける衛生的環境の確 保に関する法律（ビル管法）による規制に加え，横浜市が独自に定 めている横浜市公共建築物シックハウス対策ガイドラインを順守し ている施設である。本ガイドラインでは多数の市民が利用する公共 建築物に関して, 建築設計・工事施工の際だけでなく什器類の選定 や日常管理の際にもシックハウス症候群の防止に留意し，換気の励 行や化学製品の使用への配慮を行うとともに, 安全確認として新築. 改築時や竣工後初めての夏季などにはホルムアルデヒド，アセトア ルデヒド，トルエン，キシレン，エチルベンゼン，スチレンの 6 物 質のみではあるが室内濃度測定を実施し，室内空気質の安全確認を 行うこととされている。これらの規制による室内空気中化学物質の 低減化には一定の効果があることが示唆された。

一般住宅屋内において何らかの物質の濃度が指針值等を超過した 住宅は，77戸中で夏季が15戸 (19\%)，冬季が4戸（5.2\%）であっ た。一方, 屋内の延べ超過物質数については夏季が 25 物質, 冬季が 5 物質であり，夏季・冬季とも複数の物質が指針值等を超過した住 宅が存在した。指針值等の超過が認められた物質は夏季がホルムア ルデヒド，アセトアルデヒド，トルエン，パラジクロロベンゼンお よびTVOC，冬季がアセトアルデヒド，パラジクロロベンゼンおよ びTVOCであった。なお，一般住宅屋外においては夏季および冬 季とも調査対象とした化学物質の中では指針值等を超過した物質は なかった。
夏季において，一般住宅77戸のうち屋内でホルムアルデヒドが 指針值（100 $\left.\mathrm{\mu g} / \mathrm{m}^{3}\right)$ を超過したのは 3 戸 $(3.9 \%)$ であり，それぞ れの屋内濃度は $220 \mu \mathrm{g} / \mathrm{m}^{3}, 210 \mu \mathrm{g} / \mathrm{m}^{3}, \quad 110 \mu \mathrm{g} / \mathrm{m}^{3}$ であった。アセ トアルデヒドについては指針值 $\left(48 \mu \mathrm{g} / \mathrm{m}^{3}\right)$ を超過した住宅は77 戸中の 5 戸 $(6.5 \%)$ であり, 屋内濃度は $210 \mu \mathrm{g} / \mathrm{m}^{3}, 85 \mu \mathrm{g} / \mathrm{m}^{3}, 61$ $\mu \mathrm{g} / \mathrm{m}^{3}, \quad 54 \mu \mathrm{g} / \mathrm{m}^{3}, \quad 49 \mu \mathrm{g} / \mathrm{m}^{3}$ であった。アセトアルデヒド濃度が最 も高かった住宅は指針值の 4 倍以上の数值を示していた。トルエン については指針值 $\left(260 \mu \mathrm{g} / \mathrm{m}^{3}\right)$ を超過した住宅が77戸中 1 戸 $(1.3 \%)$ で, 屋内濃度は $330 \mu \mathrm{g} / \mathrm{m}^{3}$ であった。パラジクロロベンゼンについ ては指針值 $\left(240 \mu \mathrm{g} / \mathrm{m}^{3}\right)$ を超過した住宅が77戸中 4 戸 $(5.2 \%)$ だった。 パラジクロロベンゼンの屋内濃度が最も高かった住宅は $2200 \mu \mathrm{g} / \mathrm{m}^{3}$ と指針值の 9 倍以上の数值を示し, 以下, $1400 \mu \mathrm{g} / \mathrm{m}^{3}, 890 \mu \mathrm{g} / \mathrm{m}^{3}$, $410 \mu \mathrm{g} / \mathrm{m}^{3}$ と，それぞれ指針值の5.8倍，3.7倍，1.7倍の数值であっ た。なお，夏季の一般住宅において全測定対象物質中で最も濃度が

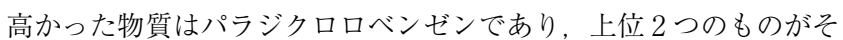
れぞれ $1 ， 2$ 番目に高い数值を示していた。TVOCについては暫定 目標值 $\left(400 \mu \mathrm{g} / \mathrm{m}^{3}\right)$ を超過した住宅が12戸（超過率16\%）だった。 TVOC が最も高い数值を示した住宅は $5000 \mu \mathrm{g} / \mathrm{m}^{3}$ と, 暫定目標值 の12倍以上の屋内濃度を示しており，この住宅はパラジクロロベン ゼンおよびアセトアルデヒドが指針值を超過していた。TVOCが暫 定目標值の 2 倍以上の屋内濃度を示した住宅はこの他に 3 戸あり， $1500 \mu \mathrm{g} / \mathrm{m}^{3}, \quad 970 \mu \mathrm{g} / \mathrm{m}^{3}, 890 \mu \mathrm{g} / \mathrm{m}^{3}$ であった。

冬季に拈いては，アセトアルデヒドについて屋内で指針值（48 $\left.\mu \mathrm{g} / \mathrm{m}^{3}\right)$ を超過した住宅が77戸中 3 戸 $(3.9 \%)$ であり，屋内濃度は それぞれ $140 \mu \mathrm{g} / \mathrm{m}^{3}, 54 \mu \mathrm{g} / \mathrm{m}^{3}, 52 \mu \mathrm{g} / \mathrm{m}^{3}$ であった。パラジクロロ ベンゼンについては，屋内にて指針值 $\left(240 \mu \mathrm{g} / \mathrm{m}^{3}\right)$ を超過した住 宅が77戸中 1 戸 (1.3\%) あり, 屋内濃度は $1600 \mu \mathrm{g} / \mathrm{m}^{3}$ と指針值の約 6.7倍を示した。この濃度は冬季の一般住宅において, 全測定対象 物質中で最も高い值であった。TVOCについては暫定目標值 (400 $\left.\mu \mathrm{g} / \mathrm{m}^{3}\right)$ を超過したのは77戸中 1 戸（1.3\%）で，屋内濃度は 1600 $\mu \mathrm{g} / \mathrm{m}^{3}$ を示した。この住宅は前述のパラジクロロベンゼンが指針值 を超過した住宅と同じ住宅であり, TVOC 超過の主因はパラジクロ ロベンゼンであった。

\section{2 公共建築物と一般住宅の比較}

公共建築物と一般住宅の空気環境について比較を行った。各建築 物ごとに，本調査で測定対象とした55物質全ての濃度の合計值（総 和）を夏季 ·冬季の屋内 · 屋外について求め, この平均值を公共建 築物と一般住宅で比較した（Fig. 2)。なお, 平均值の差の検定には Welch's t test（片側）を用いた。

屋外濃度の平均值については夏季が公共建築物と一般住宅がい ずれも $180 \mu \mathrm{g} / \mathrm{m}^{3}$ ，冬季は公共建築物と一般住宅がそれぞれ 170 $\mu \mathrm{g} / \mathrm{m}^{3}$ と $160 \mu \mathrm{g} / \mathrm{m}^{3}$ であり, 夏季・冬季とも公共建築物と一般住宅 で有意差はなかった。一方, 屋内濃度の平均值は, 夏季に公共建築 物が $330 \mu \mathrm{g} / \mathrm{m}^{3}$, 一般住宅が $620 \mu \mathrm{g} / \mathrm{m}^{3}$ と，公共建築物は一般住宅の $53 \%$ の值を，冬季に公共建築物が $210 \mu \mathrm{g} / \mathrm{m}^{3}$ ，一般住宅が $490 \mu \mathrm{g} / \mathrm{m}^{3}$ と, 公共建築物は一般住宅の $43 \%$ の值を示した。公共建築物におけ る化学物質の屋内濃度の総和は夏季, 冬季とも一般住宅より有意に 低い值だった（いずれも $\mathrm{p}<0.01 ） 。$ 建築物における衛生的環境の 確保に関する法律や横浜市公共建築物シックハウス対策ガイドライ ンの規制を受けている公共建築物の方が室内空気中化学物質の総量 が小さい傾向にあった。

公共建築物と一般住宅について, 各建築物の築年数（改築した建 築物については直近の改築からの年数）および夏季と冬季の代表的 な化学物質の屋内濃度を Fig. 3と Fig. 4に示す。なお，オゾンに関 しては夏季と冬季の屋内及び屋外濃度を Fig. 5に示す。 
Table 1 Summer concentrations of gaseous chemical compounds in indoor and outdoor air at 18 institutional buildings and 77 residential houses in Yokohama $\left(\mu \mathrm{g} / \mathrm{m}^{3}\right)$

\begin{tabular}{|c|c|c|c|c|c|c|c|c|c|c|c|c|}
\hline \multirow{3}{*}{ compounds } & \multicolumn{6}{|c|}{ Institutional building $(n=18)$} & \multicolumn{6}{|c|}{ Residential house $(n=77)$} \\
\hline & \multicolumn{3}{|c|}{ Indoor air } & \multicolumn{3}{|c|}{ Outdoor air } & \multicolumn{3}{|c|}{ Indoor air } & \multicolumn{3}{|c|}{ Outdoor air } \\
\hline & mean & median & $\max$. & mean & median & $\max$. & mean & median & max. & mean & median & $\max$. \\
\hline formaldehyde & 22 & 21 & 44 & 3.8 & 3.6 & 6.1 & 40 & 32 & 220 & 4.5 & 4.2 & 12 \\
\hline acetaldehyde & 13 & 12 & 26 & 3.1 & 2.7 & 5.8 & 21 & 14 & 210 & 3.0 & 2.8 & 6.0 \\
\hline propanal & 6.0 & 6.1 & 11 & 1.2 & 1.3 & 2.3 & 7.0 & 4.3 & 29 & 1.2 & 1.3 & 2.4 \\
\hline$i$-valeraldehyde & n.d. & n.d. & n.d. & n.d. & n.d. & n.d. & 0.1 & n.d. & 4.6 & n.d. & n.d. & n.d. \\
\hline valeraldehyde & 1.2 & 1.1 & 2.6 & 0.1 & n.d. & 0.7 & 2.6 & 1.3 & 34 & 0.2 & n.d. & 1.2 \\
\hline hexanal & 4.5 & 4.0 & 7.8 & n.d. & n.d. & 0.7 & 9.9 & 4.8 & 110 & 0.1 & n.d. & 1.2 \\
\hline heptanal & 0.1 & n.d. & 1.0 & n.d. & n.d. & n.d. & 0.7 & n.d. & 4.5 & n.d. & n.d. & n.d. \\
\hline octanal & 0.9 & 1.1 & 2.2 & 0.1 & n.d. & 2.0 & 1.7 & 1.8 & 4.8 & 0.1 & n.d. & 3.2 \\
\hline nonanal & 8.8 & 8.7 & 16 & 4.4 & 5.4 & 8.1 & 11 & 11 & 24 & 5.6 & 6.0 & 9.5 \\
\hline decanal & 2.2 & 2.6 & 5.3 & 0.2 & n.d. & 2.0 & 3.8 & 3.7 & 9.5 & 0.5 & n.d. & 3.6 \\
\hline benzaldehyde & 2.4 & 1.3 & 12 & 0.1 & n.d. & 1.1 & 1.6 & 1.3 & 8.0 & 0.1 & n.d. & 1.3 \\
\hline o-tolualdehyde & n.d. & n.d. & n.d. & n.d. & n.d. & n.d. & n.d. & n.d. & 1.0 & n.d. & n.d. & 1.0 \\
\hline$m, p$-tolualdehyde & 1.5 & 1.6 & 3.1 & 0.5 & n.d. & 1.4 & 1.6 & 1.2 & 11 & 0.8 & 0.9 & 2.2 \\
\hline 2,5-DMBA & 1.8 & 2.2 & 3.5 & 2.0 & 1.9 & 6.5 & 1.6 & 1.4 & 11 & 1.5 & 1.5 & 7.4 \\
\hline acrolein & 0.9 & 0.8 & 1.7 & 0.2 & n.d. & 1.3 & 1.0 & 0.9 & 2.5 & 0.3 & n.d. & 1.4 \\
\hline crotonaldehyde & n.d. & n.d. & 0.7 & 0.1 & n.d. & 1.1 & 0.2 & n.d. & 1.8 & n.d. & n.d. & 0.7 \\
\hline 2-nonenal & n.d. & n.d. & n.d. & n.d. & n.d. & n.d. & 0.3 & n.d. & 2.7 & n.d. & n.d. & 1.1 \\
\hline acetone & 13 & 14 & 20 & 3.2 & 2.5 & 8.0 & 23 & 16 & 200 & 3.8 & 3.4 & 16 \\
\hline 2-butanone & 1.5 & 1.3 & 4.3 & 0.4 & n.d. & 1.8 & 1.7 & 1.3 & 7.7 & 0.5 & 0.5 & 2.2 \\
\hline hexane & 2.9 & 2.1 & 7.1 & 2.3 & 1.2 & 17 & 7.0 & 2.0 & 240 & 1.3 & 1.0 & 4.3 \\
\hline heptane & 0.7 & n.d. & 3.3 & 0.1 & n.d. & 1.2 & 2.1 & n.d. & 49 & 0.1 & n.d. & 5.6 \\
\hline octane & 0.7 & n.d. & 3.5 & n.d. & n.d. & n.d. & 1.7 & n.d. & 30 & n.d. & n.d. & 0.6 \\
\hline nonane & 1.3 & n.d. & 21 & n.d. & n.d. & n.d. & 2.8 & n.d. & 36 & 0.1 & n.d. & 3.9 \\
\hline decane & 1.9 & n.d. & 25 & 0.4 & n.d. & 2.7 & 3.8 & 0.1 & 32 & 1.3 & n.d. & 8.9 \\
\hline undecane & 18 & 11 & 77 & 0.9 & n.d. & 8.7 & 19 & 9.9 & 310 & 2.5 & n.d. & 19 \\
\hline benzene & 1.4 & 1.4 & 2.7 & 1.2 & 1.5 & 2.2 & 1.2 & 1.0 & 6.5 & 1.1 & 0.9 & 9.3 \\
\hline toluene & 19 & 8.1 & 190 & 5.0 & 4.6 & 13 & 20 & 9.0 & 330 & 11 & 5.7 & 83 \\
\hline ethylbenzene & 4.4 & 3.9 & 9.8 & 2.2 & 2.1 & 5.8 & 6.7 & 2.5 & 110 & 2.2 & 2.0 & 11 \\
\hline o-xylene & 1.5 & 1.8 & 4.0 & 0.5 & n.d. & 2.5 & 2.7 & 1.8 & 19 & 0.9 & 1.0 & 4.0 \\
\hline$m, p$-xylene & 5.0 & 4.3 & 11 & 2.2 & 2.0 & 6.1 & 6.3 & 3.6 & 63 & 2.5 & 2.4 & 7.8 \\
\hline 1,3,5-TMB & 0.8 & n.d. & 9.1 & 0.1 & n.d. & 1.1 & 0.8 & n.d. & 8.4 & 0.1 & n.d. & 1.9 \\
\hline $1,2,4-\mathrm{TMB}$ & 3.5 & 1.9 & 31 & 0.4 & n.d. & 3.7 & 2.6 & 1.5 & 26 & 0.6 & n.d. & 4.9 \\
\hline 1,2,3-TMB & 0.4 & n.d. & 6.2 & n.d. & n.d. & n.d. & 0.5 & n.d. & 4.9 & n.d. & n.d. & n.d. \\
\hline$\alpha$-pinene & 1.7 & 1.2 & 7.8 & n.d. & n.d. & 0.4 & 51 & 3.3 & 1400 & 0.5 & n.d. & 5.9 \\
\hline$d$-limonene & 1.4 & n.d. & 7.1 & n.d. & n.d. & n.d. & 22 & 10 & 220 & 0.6 & n.d. & 9.3 \\
\hline$p$-dichlorobenzene & 4.5 & 4.3 & 9.9 & 1.2 & 0.6 & 4.8 & 85 & 5.6 & 2200 & 4.3 & 2.8 & 49 \\
\hline ethyl acetate & 3.0 & n.d. & 36 & 0.1 & n.d. & 1.4 & 12 & n.d. & 550 & 0.3 & n.d. & 19 \\
\hline butyl acetate & 0.9 & n.d. & 14 & 0.2 & n.d. & 3.0 & 8.3 & n.d. & 100 & 0.2 & n.d. & 5.6 \\
\hline ozone & 3.9 & 3.1 & 7.7 & 27 & 24 & 65 & 7.7 & 5.2 & 43 & 32 & 26 & 85 \\
\hline hydrogen chloride & 0.9 & 0.7 & 2.3 & 2.1 & 1.1 & 18 & 1.6 & 1.5 & 13 & 1.6 & 1.6 & 3.2 \\
\hline nitrogen dioxide & 9.9 & 8.3 & 19 & 16 & 12 & 49 & 16 & 13 & 85 & 16 & 13 & 49 \\
\hline sulful dioxide & 0.4 & 0.6 & 1.0 & 2.1 & 1.1 & 6.0 & 0.6 & 0.6 & 3.8 & 1.4 & 0.9 & 6.2 \\
\hline formic acid & 22 & 22 & 31 & 14 & 13 & 25 & 25 & 22 & 80 & 12 & 12 & 25 \\
\hline acetic acid & 100 & 85 & 230 & 70 & 54 & 170 & 150 & 120 & 550 & 51 & 34 & 190 \\
\hline ammonia & 44 & 45 & 61 & 13 & 15 & 19 & 37 & 29 & 160 & 8.4 & 7.2 & 23 \\
\hline temperature $\left({ }^{\circ} \mathrm{C}\right)$ & 28 & 28 & 31 & 28 & 29 & 29 & 28 & 28 & 33 & 26 & 27 & 29 \\
\hline humidity (\%) & 58 & 58 & 66 & 73 & 75 & 81 & 66 & 67 & 82 & 79 & 78 & 94 \\
\hline
\end{tabular}

n.d., not detected

\section{2.1 カルボニル化合物}

カルボニル化合物の屋内平均值について, 公共建築物の数值が一 般住宅よりも低いものは19物質中で夏季は16物質, 冬季は14物質と 過半数にのぼった。一方, 屋外平均值については夏季が 9 物質, 冬 季は 4 物質であった。屋内にて特に夏季, 公共建築物の方が一般住 宅よりも平均值が低くなっている物質が多かった。

ホルムアルデヒドおよびアセトアルデヒドの平均值に関し, 屋内 においては, どちらの物質とも夏季と冬季を比較すると夏季の平均 值が大きく，公共建築物と一般住宅を比較すると一般住宅の平均值 が大きかった。公共建築物と一般住宅とで平均値の差の検定を行っ たところ, 屋内におけるホルムアルデヒドおよびアセトアルデヒド
はいずれも夏季・冬季ともに一般住宅の平均值が公共建築物よりも 有意に高い值を示していた（夏季・冬季ホルムアルデヒドおよび冬 季アセトアルデヒド : $\mathrm{p}<0.01$, 夏季アセトアルデヒド : $\mathrm{p}<0.05)$ 。 また，ノナナールについては夏季・冬季とも公共建築物屋内の平均 值が一般住宅屋内よりも有意に低い值であった（夏季 : $\mathrm{p}<0.05$, 冬季 : $\mathrm{p}<0.01)$ 。なお, 屋外に扔ける平均值についてはホルムアル デヒド, アセトアルデヒド, ノナナールともそれぞれの屋内よりも 低い值であった。ホルムアルデヒド及びアセトアルデヒドがシック 八ウス症候群の代表的な原因物質であることは従来から知られてい る。しかし, 未だに厚労省が示した室内濃度指針值を超過する一般 住宅もある中で, 公共建築物の室内濃度が低めの值を示した点にお 
Table 2 Winter concentrations of gaseous chemical compounds in indoor and outdoor air at 18 institutional buildings and 77 residential houses in Yokohama $\left(\mu \mathrm{g} / \mathrm{m}^{3}\right)$

\begin{tabular}{|c|c|c|c|c|c|c|c|c|c|c|c|c|}
\hline \multirow{3}{*}{ compounds } & \multicolumn{6}{|c|}{ Institutional building $(n=18)$} & \multicolumn{6}{|c|}{ Residential house $(n=77)$} \\
\hline & \multicolumn{3}{|c|}{ Indoor air } & \multicolumn{3}{|c|}{ Outdoor air } & \multicolumn{3}{|c|}{ Indoor air } & \multicolumn{3}{|c|}{ Outdoor air } \\
\hline & mean & median & $\max$. & mean & median & $\max$. & mean & median & $\max$ & mean & median & max. \\
\hline formaldehyde & 6.3 & 5.8 & 10 & 1.9 & 1.8 & 2.9 & 13 & 11 & 36 & 1.8 & 1.6 & 5.5 \\
\hline acetaldehyde & 6.7 & 6.7 & 8.7 & 2.9 & 2.8 & 4.7 & 20 & 16 & 140 & 2.6 & 2.6 & 5.9 \\
\hline propanal & 1.8 & 1.1 & 6.1 & 0.5 & 0.6 & 1.0 & 3.9 & 2.6 & 18 & 0.6 & 0.5 & 2.0 \\
\hline i-valeraldehyde & 0.5 & 0.6 & 1.0 & 0.4 & 0.5 & 1.3 & 0.5 & 0.6 & 1.6 & 0.4 & 0.5 & 1.6 \\
\hline valeraldehyde & 0.6 & 0.7 & 1.4 & 0.7 & 0.7 & 1.6 & 0.9 & 0.7 & 6.0 & 0.6 & 0.6 & 1.7 \\
\hline hexanal & 1.9 & 1.7 & 5.9 & 0.5 & 0.7 & 1.2 & 3.5 & 2.3 & 23 & 0.7 & 0.8 & 2.0 \\
\hline heptanal & 1.0 & 1.1 & 2.1 & 1.0 & 0.9 & 2.0 & 1.1 & 1.0 & 4.3 & 0.9 & 0.9 & 2.6 \\
\hline octanal & 1.1 & 1.1 & 1.5 & 1.1 & 1.1 & 1.8 & 1.4 & 1.2 & 3.5 & 1.0 & 1.1 & 2.9 \\
\hline nonanal & 2.0 & 2.1 & 3.6 & 1.3 & 1.4 & 2.1 & 3.3 & 2.6 & 18 & 1.4 & 1.3 & 6.7 \\
\hline decanal & 1.4 & 1.5 & 2.3 & 1.7 & 1.6 & 3.5 & 1.6 & 1.5 & 3.4 & 1.5 & 1.5 & 4.4 \\
\hline benzaldehyde & 1.0 & 0.9 & 2.5 & 0.7 & 0.6 & 1.3 & 0.9 & 0.7 & 4.5 & 0.5 & 0.6 & 1.4 \\
\hline o-tolualdehyde & 0.5 & 0.4 & 1.4 & 0.6 & 0.8 & 1.3 & 1.6 & 0.8 & 61 & 0.6 & 0.8 & 2.1 \\
\hline$m, p$-tolualdehyde & 1.0 & 1.0 & 2.3 & 0.7 & 0.8 & 1.3 & 2.5 & 0.9 & 120 & 0.7 & 0.8 & 2.3 \\
\hline 2,5-DMBA & 1.1 & 1.1 & 2.7 & 1.0 & 1.1 & 1.6 & 1.2 & 1.1 & 5.2 & 1.0 & 1.1 & 2.3 \\
\hline acrolein & 0.5 & 0.4 & 1.0 & 0.4 & 0.3 & 0.8 & 0.5 & 0.4 & 3.7 & 0.3 & 0.3 & 0.9 \\
\hline crotonaldehyde & 0.5 & 0.4 & 1.4 & 0.5 & 0.5 & 0.9 & 0.5 & 0.4 & 5.1 & 0.4 & 0.4 & 1.5 \\
\hline 2-nonenal & 0.6 & 0.4 & 1.7 & 0.7 & 0.9 & 1.9 & 0.7 & 0.9 & 2.2 & 0.8 & 0.9 & 4.5 \\
\hline acetone & 11 & 11 & 19 & 4.2 & 4.0 & 8.0 & 30 & 15 & 1000 & 3.7 & 3.3 & 9.7 \\
\hline 2-butanone & 2.1 & 1.6 & 6.4 & 1.2 & 1.1 & 2.5 & 1.7 & 1.2 & 23 & 0.9 & 0.7 & 4.2 \\
\hline hexane & 8.8 & 2.9 & 100 & 1.6 & 1.2 & 6.0 & 2.3 & 1.3 & 17 & 2.6 & 0.8 & 96 \\
\hline heptane & 1.2 & 0.9 & 4.1 & 0.2 & n.d. & 0.8 & 1.9 & 0.6 & 32 & 0.1 & n.d. & 1.0 \\
\hline octane & 0.4 & 0.3 & 2.0 & 0.1 & n.d. & 0.3 & 2.4 & n.d. & 110 & 0.1 & n.d. & 0.9 \\
\hline nonane & 0.6 & 0.6 & 2.1 & 0.4 & 0.4 & 1.3 & 3.8 & 0.6 & 38 & 0.4 & 0.3 & 2.7 \\
\hline decane & 1.3 & 0.9 & 6.3 & 1.2 & 0.9 & 4.8 & 5.5 & 1.9 & 54 & 1.6 & 1.3 & 6.5 \\
\hline undecane & 3.9 & 4.0 & 8.3 & 1.9 & 1.8 & 7.3 & 9.6 & 3.0 & 140 & 2.1 & 1.8 & 8.7 \\
\hline benzene & 2.0 & 1.7 & 4.3 & 1.6 & 1.2 & 3.3 & 1.6 & 1.5 & 10 & 1.4 & 1.3 & 4.1 \\
\hline toluene & 13 & 9.1 & 52 & 9.4 & 6.7 & 56 & 8.3 & 6.0 & 53 & 5.4 & 3.6 & 55 \\
\hline ethylbenzene & 3.3 & 3.0 & 6.3 & 2.2 & 2.0 & 4.5 & 2.2 & 1.9 & 6.5 & 1.4 & 1.2 & 4.3 \\
\hline o-xylene & 1.7 & 1.6 & 3.3 & 1.2 & 1.2 & 2.6 & 1.8 & 1.2 & 7.4 & 1.0 & 0.9 & 4.4 \\
\hline$m, p$-xylene & 4.7 & 4.3 & 7.2 & 3.5 & 3.5 & 6.3 & 4.5 & 3.3 & 16 & 2.8 & 2.7 & 6.3 \\
\hline 1,3,5-TMB & 0.9 & 0.7 & 2.4 & 0.4 & 0.4 & 1.3 & 1.0 & 0.6 & 6.2 & 0.5 & 0.4 & 1.8 \\
\hline 1,2,4-TMB & 2.3 & 1.9 & 8.2 & 1.5 & 1.3 & 2.9 & 3.2 & 1.5 & 21 & 1.5 & 1.2 & 4.2 \\
\hline 1,2,3-TMB & 0.4 & 0.3 & 1.5 & 0.2 & 0.3 & 0.7 & 0.8 & 0.3 & 7.0 & 0.3 & 0.2 & 1.0 \\
\hline$\alpha$-pinene & 0.1 & n.d. & 0.8 & n.d. & n.d. & 0.3 & 7.8 & 2.0 & 120 & 0.1 & n.d. & 1.6 \\
\hline$d$-limonene & 2.1 & 2.3 & 5.4 & n.d. & n.d. & n.d. & 22 & 14 & 200 & 0.2 & n.d. & 3.3 \\
\hline$p$-dichlorobenzene & 2.5 & 2.0 & 7.1 & 0.2 & n.d. & 1.3 & 29 & 1.7 & 1600 & 0.9 & n.d. & 34 \\
\hline ethyl acetate & 3.1 & 1.9 & 22 & 0.4 & n.d. & 1.9 & 2.0 & n.d. & 56 & 0.5 & n.d. & 18 \\
\hline butyl acetate & 0.4 & n.d. & 1.5 & 0.3 & n.d. & 2.0 & 1.7 & n.d. & 14 & 0.2 & n.d. & 1.8 \\
\hline ozone & 0.8 & 0.7 & 2.6 & 23 & 24 & 35 & 1.0 & 0.7 & 6.4 & 29 & 30 & 55 \\
\hline hydrogen chloride & 1.6 & 0.8 & 10 & 1.4 & 1.0 & 5.4 & 2.0 & 0.8 & 20 & 1.7 & 0.6 & 25 \\
\hline nitrogen dioxide & 37 & 32 & 81 & 43 & 36 & 84 & 150 & 40 & 1300 & 28 & 23 & 110 \\
\hline sulful dioxide & 0.8 & 0.8 & 3.0 & 2.1 & 1.8 & 5.5 & 0.8 & 0.6 & 12 & 1.5 & 1.4 & 5.4 \\
\hline formic acid & 9.2 & 9.0 & 16 & 9.4 & 8.8 & 16 & 32 & 13 & 310 & 8.6 & 9.1 & 20 \\
\hline acetic acid & 45 & 40 & 96 & 32 & 28 & 81 & 87 & 76 & 330 & 41 & 31 & 150 \\
\hline ammonia & 18 & 16 & 32 & 6.0 & 4.6 & 17 & 16 & 13 & 80 & 5.0 & 3.3 & 42 \\
\hline temperature $\left({ }^{\circ} \mathrm{C}\right)$ & 20 & 20 & 23 & 6.4 & 6.3 & 9.5 & 16 & 16 & 24 & 5.3 & 5.4 & 15 \\
\hline humidity（\%) & 41 & 41 & 52 & 59 & 61 & 76 & 46 & 45 & 77 & 45 & 42 & 84 \\
\hline
\end{tabular}

n.d., not detected

いて, 公共建築物の室内空気質は一般住宅よりも良好であると言え る。

\section{2. 2 VOCs}

VOCs の屋内平均値について, 公共建築物の数值が一般住宅より も低いものは28物質中で夏季は21物質, 冬季は18物質と過半数にの ぼった。一方，屋外については28物質中で夏季が13物質，冬季は11 物質であった。屋内にて特に夏季，公共建築物の方が一般住宅より も平均值が低くなっている物質が多かった。

パラジクロロベンゼンに関し, 夏季屋内の平均值は公共建築物が 一般住宅の $5.3 \%$ の值を示したのに対し，中央值は $77 \%$ の值であっ た。また, 冬季屋内の平均值は公共建築物が一般住宅の $8.6 \%$ の值
だったのに対し，公共建築物と一般住宅の中央值はほぼ同じ值であ るなど, 特に一般住宅屋内での平均值が高く, かつ, 平均值と中央 值とが乘離した数值となっていた。各建築物におけるパラジクロロ ベンゼンの室内濃度は指針值の $240 \mu \mathrm{g} / \mathrm{m}^{3}$ に比べ, 夏季に扔いて最 大で $2200 \mu \mathrm{g} / \mathrm{m}^{3}$ など，突出した屋内濃度を示した一部の一般住宅 がある一方で, 残り 9 割の一般住宅（77戸中69戸）および全公共建 築物の屋内濃度は指針值の半分の值である $120 \mu \mathrm{g} / \mathrm{m}^{3}$ 以下であった。 また，冬季に扔いても一般住宅屋内にて $1600 \mu \mathrm{g} / \mathrm{m}^{3}$ と指針值（240 $\left.\mu \mathrm{g} / \mathrm{m}^{3}\right)$ を超えて突出した数值を示した住宅（1戸）があったが, 他の一般住宅（77戸中76戸）㧍よび全公共建築物の屋内濃度は指針 值の半分の值以下だった。パラジクロロベンゼンの濃度分布にこの 

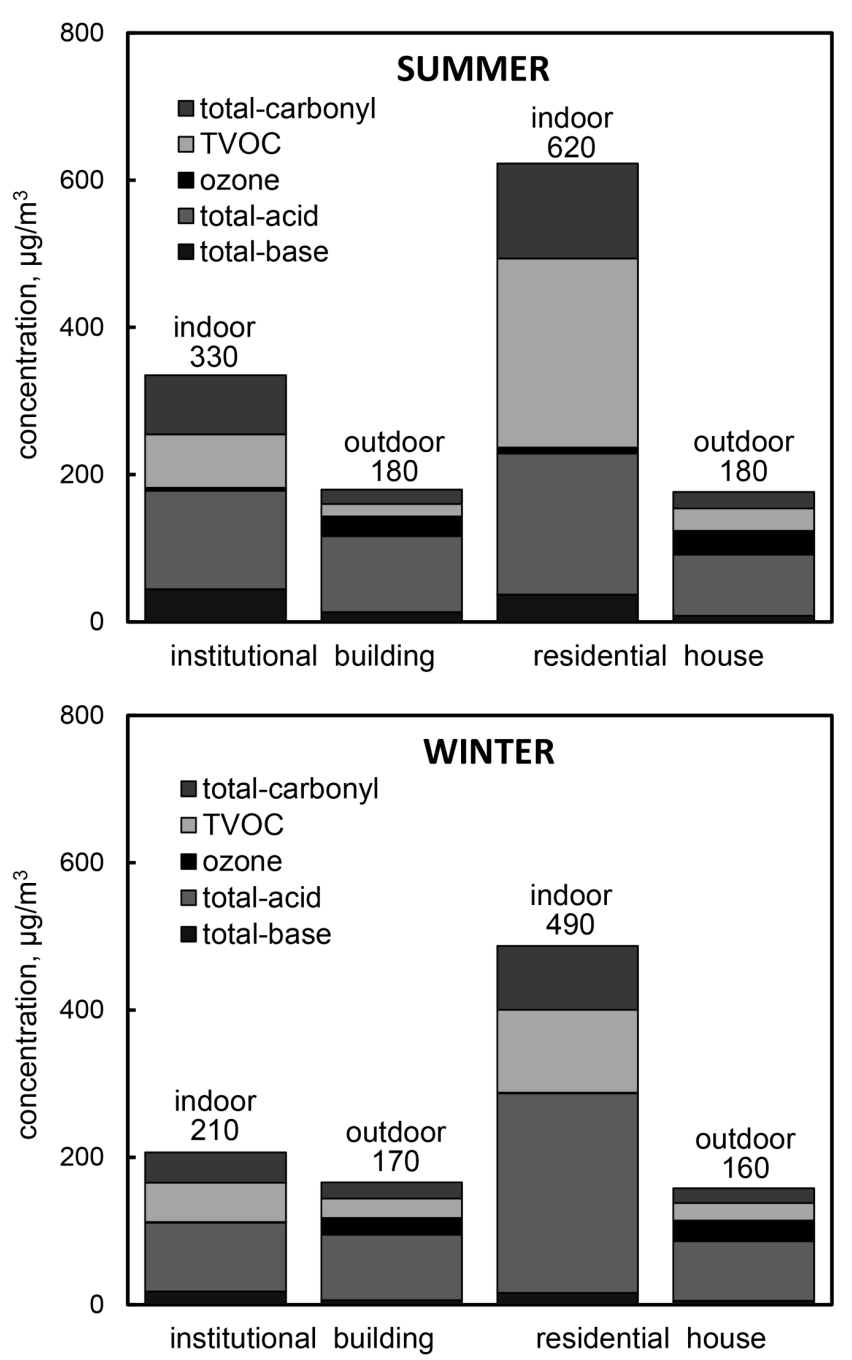

Fig. 2 Mean concentrations of total gaseous compounds in indoor and outdoor air at 18 institutional buildings and 77 residential houses in summer and in winter

ような特徵があったため, 平均值と中央值とが乘離したものと思わ れる。これは，パラジクロロベンゼンの発生源となる防虫・防臭剂 などの化学製品（パラジクロロベンゼン製剤）を使用している住宅 と使用していない住宅とで室内濃度が大きく分かれたことが原因と 考えられる。

公共建築物と一般住宅とでパラジクロロベンゼンの平均值につい て有意差検定を行ったところ, 夏季屋内において, 一般住宅の平均 值は公共建築物よりも有意に高い值を示した $(\mathrm{p}<0.05)$ 。冬季屋内 については公共建築物と一般住宅とで有意差はなく, また, 公共建 築物㧍よび一般住宅とも $90 \%$ タイル值が指針值の $1 / 10$ 以下の数值 であり，いずれも室内濃度は低い值を示していた。一般住宅におい てパラジクロロベンゼンの使用に関しては特に規制がないが, 横浜 市公共建築物シックハウス対策ガイドラインでは公共建築物の運営 にあたり，日常管理としてシックハウス症候群を引きおこす可能性 のある化学物質の使用を避けるなどの配慮を行うこととしている。 このような規制も公共建築物のパラジクロロベンゼンの屋内濃度を 下げる一因となっていると思われる。

トルエンの屋内に打ける平均值は, 夏季, 公共建築物は一般住宅 の $95 \%$ の值，冬季は $160 \%$ の值であった。公共建築物と一般住宅と で夏季の平均值に有意差はなかったが, 冬季については公共建築物 の方が一般住宅よりも有意に高い数值を示した $(\mathrm{p}<0.05)$ 。しかし，

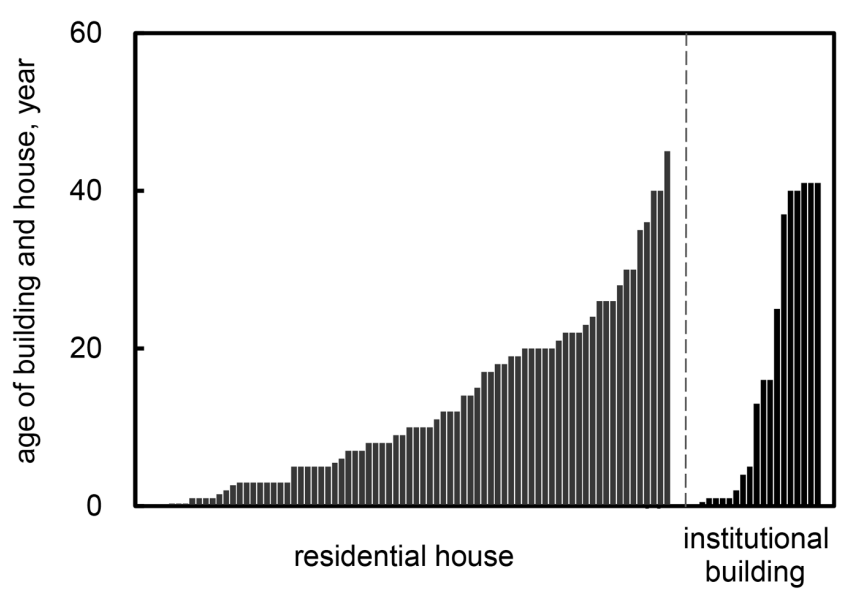

Fig. 3 Ages of 77 residential houses and 18 institutional buildings

公共建築物および一般住宅とも $90 \%$ タイル值が指針值の $1 / 10$ 以下 の数值であり，いずれも室内濃度は低い值を示していた。屋外平均 值は公共建築物, 一般住宅とも屋内の数值よりも低い值であった。

キシレンの屋内に㧍ける平均值は夏季, 公共建築物が一般住宅の 73\%の值を示したが, 冬季はほぼ同じ值を示した。夏季, 冬季とも 公共建築物と一般住宅の屋内濃度に有意差はなく, 公共建築物拈よ び一般住宅とも $90 \%$ タイル值が指針值の $1 / 10$ 以下の数值と, 室内濃 度は低い值を示していた。また, 屋外では公共建築物と一般住宅の 夏季の值がいずれも屋内の数值より低い值であった。

エチルベンゼンの測定值は厚労省の示した室内濃度指針值よりも 極めて低く, 夏季に $110 \mu \mathrm{g} / \mathrm{m}^{3}$ を示した一般住宅が 2 戸あった他は, 公共建築物も含めた全ての調査対象施設の屋内濃度は夏季 · 冬季と も $20 \mu \mathrm{g} / \mathrm{m}^{3}$ 未満の数值であった。

$a$-ピネンおよび $d-$ リモネンはいずれもテルペン類であるが, こ れら 2 物質については公共建築物と一般住宅の屋内濃度に大きく相 違が見られた。屋内において, 夏季に $a$-ピネンの平均值は公共建 築物が一般住宅の $3.3 \%, d$-リモネンは $6.4 \%$ の值を示した。冬季に おいては $\alpha$-ピネンの平均值は公共建築物が一般住宅の $1.3 \%, d-リ$ モネンは9.5\%の值を示した。一方, 屋外における $a$-ピネンおよび $d$-リモネンの平均值は公共建築物および一般住宅の夏季 · 冬季とも 屋内より数值が低かった。公共建築物と一般住宅とで平均值の差の 検定を行ったところ, $a$ - ピネンおよび $d$-リモネンの屋内平均值は 夏季・冬季ともに一般住宅の值が公共建築物よりも有意に高い数值 を示していた（いずれも $\mathrm{p}<0.01 ） 。 一$ 般的に $\boldsymbol{a}$-ピネンの主な発生 源としては木材が知られている。リモネンは木材からも放散するが, 柑橘類や香料からの放散も多い。今回調査対象とした一般住宅は木 造の住宅の割合が77軒中 41 軒 (53\%) と過半数にのぼったのに対し, 公共建築物は全施設が鉄筋コンクリート製であった。また, 本調査 において公共建築物の屋内での測定箇所は事務室としたが, 事務室 は一般家庭の屋内とは異なり木製の什器類や柑橘類, 香料などはほ とんど存在しない。これらが公共建築物および一般住宅における $a$ - ピネンおよび $d$-リモネンの屋内濃度の相違の原因となっている と考えられる。

\section{2.3 無機ガス状物質}

オゾンについて, 夏季, 公共建築物における屋内濃度は一般住宅 の $51 \%$ の值であり, 有意に低かった $(\mathrm{p}<0.01)$ 。一方, 夏季の公共 建築物と一般住宅の屋外平均值には有意差はなかった。また, 公共 建築物, 一般住宅とも屋内のオゾンは屋外よりも有意に低い值を示

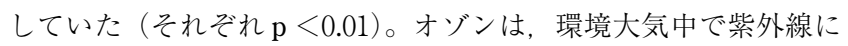



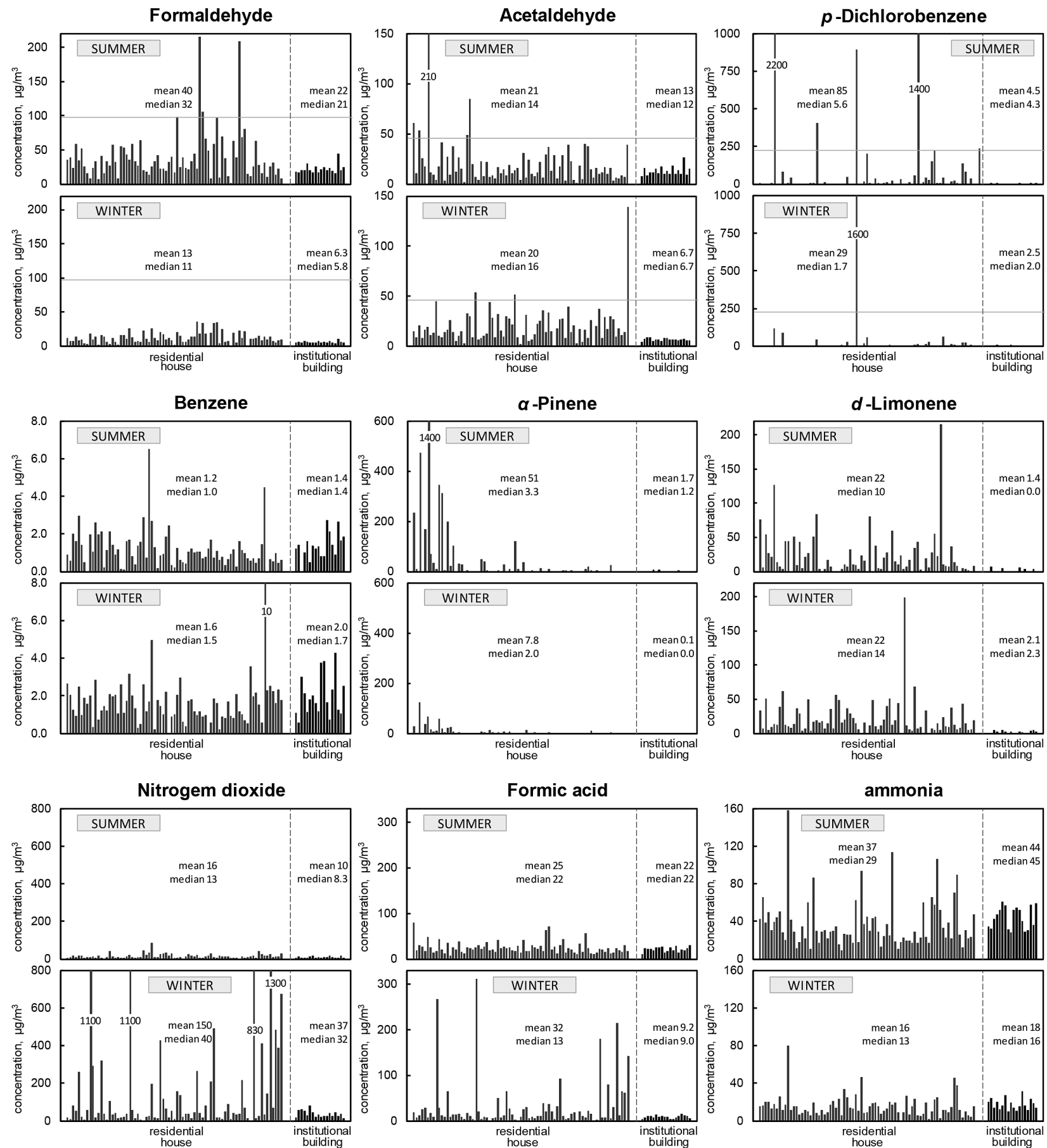

Fig. 4 Concentrations of gasous chemical compounds in indoor air at 77 residential houses and 18 institutional buildings in summer and winter

より酸素が酸化され生成する。外気から屋内に流入したオゾンは比 較的速い速度で分解するとされている5)。夏季の場合，一般住宅に おいては空開けや換気扇をまわすなどの方法で直接外気を屋内に導 入ことが多い。本調査に扔いては，アンケート調査で回答が得られ た一般住宅のうちの $94 \%$ 夏季に空を開けたり，換気扇を回したり して外気を導入していた。したがって，換気により濃度が低くなっ たことが考えられる。本調査における公共建築物と一般住宅との才 ゾン濃度の相違は, 換気システムの相違と関連する可能性がある。

一方, 冬季においては屋内に拈けるオゾンの平均值は公共建築物 と一般住宅とで有意差はなかった。さらに, 公共建築物および一般 住宅とも, 屋内の平均值は屋外よりも有意に低い值を示していた(そ
れぞれ $\mathrm{p}<0.01)$ 。冬季においては夏季と異なり一般住宅において 空開けによる換気が少なくなるため, 夏季と比較して冬季は公共建 築物と一般住宅の屋内平均值の差が減少したと推測される。

二酸化窒素について, 冬季の屋内における平均值は公共建築物が 一般住宅の $25 \%$ の值であり, 有意に低かった（p<0.01）。また，公 共建築物において屋内と屋外の平均值に有意差はなかったが，一般 住宅の屋内平均值は屋外よりも有意に高い值を示した $(\mathrm{p}<0.01)$ 。 冬季の二酸化窒素について, 公共建築物と一般住宅に扔ける屋内濃 度と屋外濃度の相関掞よび各建築物ごとの屋内 / 屋外濃度比 (以下, $\mathrm{I} / \mathrm{O}$ 比）を求めた。その結果, 公共建築物における屋内濃度と屋外 濃度の相関は $\mathrm{r}=0.604$,一般住宅における相関は $\mathrm{r}=0.089$ だったが, 

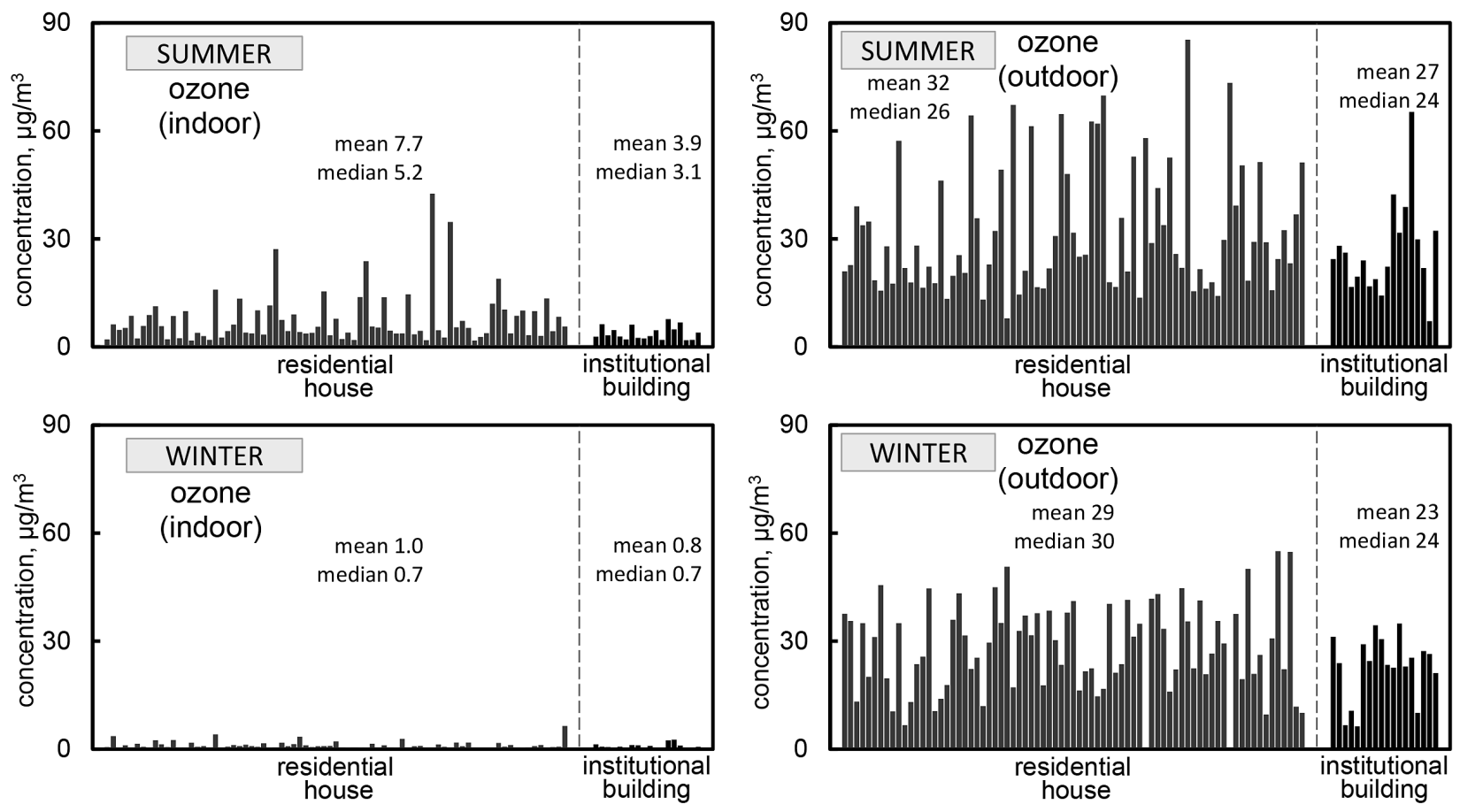

Fig. 5 Concentrations of ozone in indoor and outdoor air at 77 residential houses and 18 institutional buildings in summer and winter

$\mathrm{I} / \mathrm{O}$ 比が2.5を超えた建築物を除外して相関を調べたところ, 公共 建築物における相関は $\mathrm{r}=0.877$, 一般住宅における相関は $\mathrm{r}=0.731$ となった。公共建築物, 一般住宅とも I/O 比が 2.5 以下の建築物に 関しては, 屋内濃度と屋外濃度の相関が高いことから屋内の二酸化 窒素の由来が外気である可能生が考えられる。また, 逆に I/O 比 が2.5を超える建築物に関しては, 屋内に二酸化窒素の発生源が別 に存在する可能性がある。冬季の二酸化窒素に関して, 公共建築物

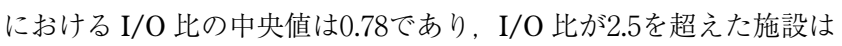
18 施設中 1 施設であった。一方, 一般住宅における I/O 比の中央 值は2.1であり，77戸中30戸の一般住宅で I/O 比が2.5を超えていた。 公共建築物と異なり, 一般住宅屋内には二酸化窒素の発生源が存在 することが示唆される。二酸化窒素は燃焼によって発生するが, ア ンケート調査の結果, 公共建築物においては測定箇所が事務フロア でありガスコンロや燃焼系暖房器具を使用している施設はなかっ たが，一般住宅においては77戸中51戸でガスコンロを，18戸で燃焼 系暖房器具を使用していた。これらのことから，冬季屋内における 公共建築物と一般住宅の二酸化窒素濃度の相違は, 屋内でのガスコ ンロや燃焼系暖房器具の使用状況の相違に由来すると考えられる。 さらに，一般住宅に扔いて燃焼系暖房器具を使用していた住宅18戸 のうちの16戸では二酸化窒素の I/O 比が2.5を超えていた。燃焼系 暖房器具の使用が室内の二酸化窒素濃度の上昇に大きく寄与して いるものと思われる。

一方, 夏季において, 二酸化窒素の屋内平均值は公共建築物が一 般住宅の $62 \%$ の值であった。これは有意に低い值であったが $(\mathrm{p}<$ 0.01), その差は冬季屋内ほどではなかった。公共建築物の屋内平 均值は屋外よりも有意に低い值だったが $(\mathrm{p}<0.05)$, 一般住宅で は屋内と屋外の平均值に有意差はなかった。アンケート調査による と, 夏季には一般住宅屋内での燃焼系暖房器具の使用はなく, ガス コンロの使用時間についても一般住宅の平均が約 0.9 時間という回 答であった。夏季は一般住宅屋内に打ける二酸化窒素の発生が少な かったため, 一般住宅に拈いても屋内の濃度があまり上昇せず, 屋 外とほぼ同じ值にとどまったと考えられる。また, 公共建築物で は冬季・夏季とも屋内濃度の平均值が屋外よりも若干低い值であっ
た。冬季と同様に夏季においても公共建築物では二酸化窒素の発生 源となり得る燃焼系暖房器具やガスコンロの使用がなかったため 数值が上昇しなかったと考えられる。

ギ酸について, 夏季・冬季とも公共建築物屋内の平均值は一般住 宅よりも有意に低かった（夏季 : $\mathrm{p}<0.05$, 冬季 : $\mathrm{p}<0.01$ )。屋外 の平均值については, 公共建築物と一般住宅が夏季 · 冬季ともそれ ぞれ同様な值を示した。ギ酸の室内濃度は二酸化窒素との相関が 高いことからギ酸の発生源の一つとして燃焼系器具が推測できる。 Fig. 6に冬季に打ける公共建築物および一般住宅屋内のギ酸濃度と 二酸化窒素濃度との関係を示す。冬季の一般住宅屋内で $\mathrm{r}=0.958$ と非常に高い相関が認められた。前述のとおり冬季の一般住宅屋内 においては燃焼系器具が使われていたが, 公共建築物ではその使用 がなかったため, 冬季の一般住宅屋内ではギ酸と二酸化窒素との相 関が高くなったと考えられる。

酷酸については, 夏季・冬季とも公共建築物屋内の平均值は一般

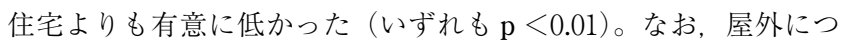
いては, 夏季 · 冬季とも公共建築物と一般住宅の平均値に有意差は なかった。

二酸化硫黄については, 夏季・冬季とも公共建築物と一般住宅の 屋内の平均值に有意差はなかった。一方, 夏季 · 冬季の公共建築物 および一般住宅のそれぞれにおいて, 屋内の平均值は屋外よりも有 意に低い值を示した（いずれも $\mathrm{p}<0.01 ） 。$

屋内に打けるアンモニアの平均值は, 夏季には公共建築物が一 般住宅の $120 \%$ の值であり, 有意に高かった（p<0.05）。また，冬 季には公共建築物が一般住宅の $110 \%$ の值を示したが, 有意差はな かった。人間はアンモニアの発生源であるが, 調査対象とした公共 建築物は全て市民利用施設であり, 屋内には多くの人が在室してい る。また，公共建築物の躯体にはコンクリートが多く用いられてい るが, コンクリートからはアンモニアが発生することが報告されて いる20)。特に夏季, 公共建築物のアンモニアがやや高い值を示した のはこれらが一因であると考えられる。一方, 屋外の平均值につ いては, 公共建築物と一般住宅がそれぞれ屋内よりも低い值であっ た。なお, 都市部屋外におけるアンモニアの発生源の一つとして自 

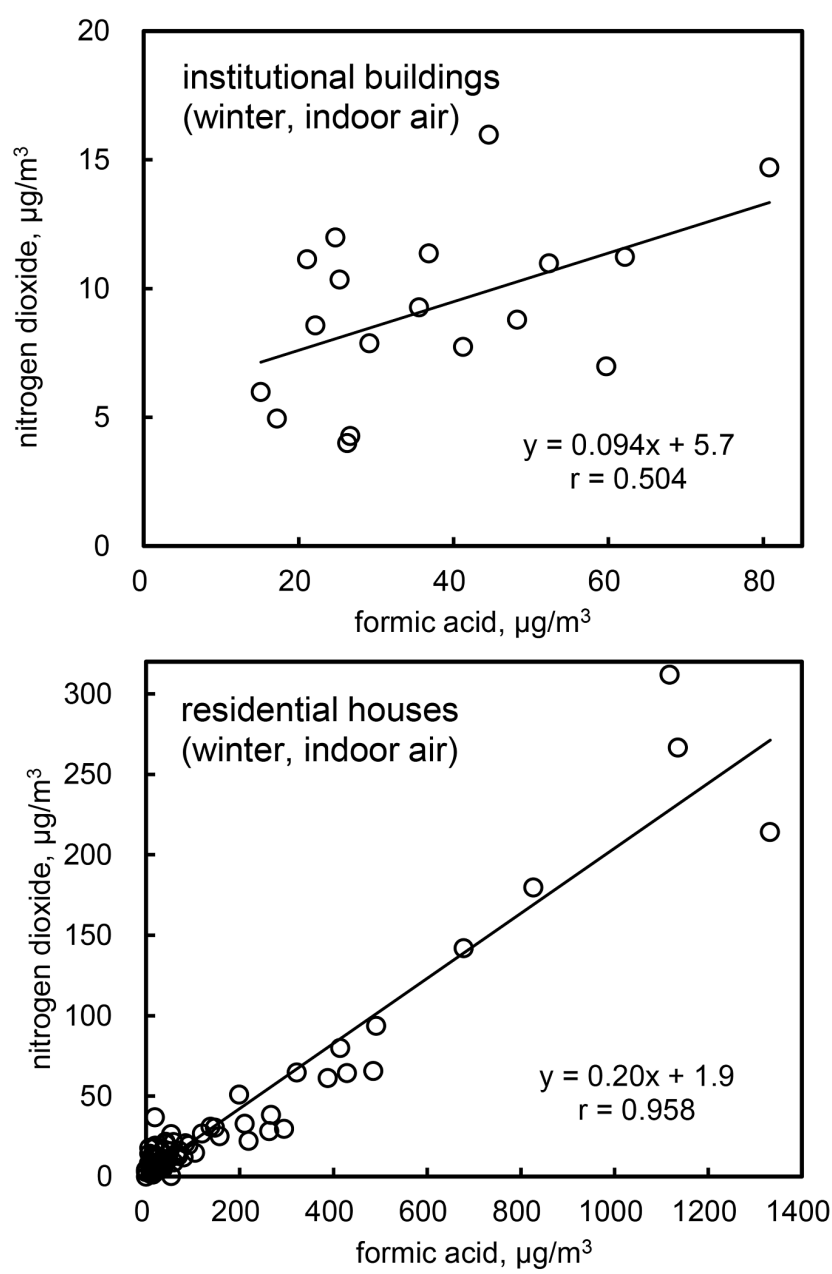

Fig. 6 Relationship between formic acid and nitrogen dioxide concentrations measured in indoor and outdoor air at 77 residential houses and 18 institutional buildings

動車の排気ガスが報告されている21)。公共建築物は幹線道路周辺な どの比較的交通の便の良い場所に建設されることが多いため, 公共 建築物の屋外濃度の平均值は一般住宅屋外よりも高い数值を示した 可能性がある。

\section{3 個人の一日暴露濃度の推定}

調査対象の公共建築物は市民利用施設であると同時に, そこで働 いている人にとっては職場でもある。今回調査を行った一般住宅の 中には，公共建築物での勤務者自宅が一部含まれる。一般住宅77戸 の中から，公共建築物18施設の勤務者自宅24戸を抽出し，職場（公 共建築物18施設）抢よび自宅（抽出された一般住宅24戸）の室内空 気質と各場所での在室時間を併せて検証することにより，個人 $(24$ 名)の一日暴露量の評価を試みた。なお,一日の暴露濃度は, 職場(公 共建築物屋内）で過ごす時間を 9 時間, 屋外で過ごす時間を 1 時間, 自宅屋内で過ごす時間を14時間と仮定し，それぞれの 24 時間平均濃 度に，9/24，1/24，14/24を乗じたものを合計して暴露濃度を算出 した。な掞, 屋外濃度には公共建築物と一般住宅に扔ける各屋外濃 度の平均值を採用した。24名の職場（公共建築物）屋内，屋外拉よ び自宅（一般住宅）屋内における夏季および冬季の暴露濃度をそれ ぞれ Fig. 7a および Fig. 7b に示す。人は室内で過ごすことが多いた め, 室内空気中化学物質が多いと暴露量も増える。特に, 比較的長 時間を過ごすことが多い自宅の室内空気質は，暴露に対する寄与が 大きくなる。今回の調査においては公共建築物屋内よりも一般住宅
屋内で高い濃度を示した物質が多かったために, 在室設定時間が加 味された結果, 自宅の室内空気質の影響がより大きくなっている ケースが多かった。特にパラジクロロベンゼン， $\alpha$-ピネンおよび $d$ リモネンや，冬季には二酸化窒素拉よびギ酸などの物質でこのよう な傾向が目立った。その一方で，オゾンについては屋外で過ごす時 間を一日のうち 1 時間と短時間に設定したにもかかわらず，屋外空 気質の寄与が大きかった。特に冬季のオゾンについては, 屋外の数 值に比べて屋内の数值が大幅に小さかったため, 24 名中の16名, つ まり 3 分の 2 のケースについては在室設定時間が加味されているに もかかわらず, オゾン暴露濃度の $\mathrm{I} / \mathrm{O}$ 比が 1 を下回り, 屋外から の暴露の方が屋内からの暴露よりも大きいと算出された。

\section{謝 辞}

本研究は厚生労働科学研究「シックハウス症候群の発生予防 · 症 状軽減のための室内環境の実態調査と改善対策に関する研究」の一 環として行われた。測定に御協力頂いた方々に深謝申し上げます。

\section{要 約}

居住空間の安全性確保を目的として, 横浜市内の公共建築物 18 施 設と, 横浜市およびその周辺地域にある一般住宅77戸の屋内・屋外 において，空気環境中の広範囲にわたる化学物質を測定することが 可能な各種拡散サンプラーを用いたガス状化学物質の測定を行い, 夏季および冬季における污染の実態把握を行った。

公共建築物18施設においては夏季および冬季の屋内・屋外とも本 研究で調査対象とした化学物質のうち, 厚労省が策定した室内濃度 指針值および暫定目標値を超過した物質はなく，室内空気質は良好 であると考えられた。一方，一般住宅屋内においては77戸中で夏季 15戸 (19\%)，冬季 4戸（5％）の住宅にて何らかの物質の濃度が 指針值等を超過した。このなかには複数の物質が指針值等を超過し た一般住宅もあった。

また，今回調査を行った公共建築物と一般住宅の室内環境につい て比較を行ったところ, 公共建築物の室内空気中化学物質の総和の 平均值は一般住宅の $53 \%$ (夏季) および $43 \%$ (冬季) であり, 公共 建築物に打ける化学物質の屋内濃度の総和は夏季, 冬季とも一般住 宅より有意に低い值を示した（いずれも $\mathrm{p}<0.01 ） 。$

さらに，一般住宅の中から公共建築物18施設の勤務者自宅24戸を 抽出し, 職場および自宅の各室内空気質に在室時間を併せて検証す ることで, 個人の一日暴露量の評価を試みた。今回の調査に扔いて は公共建築物屋内よりも一般住宅屋内で高い濃度を示した物質が多 かったために, 在室設定時間が加味された結果, 自宅の室内空気質 の影響がより大きくなっているケースが多かった。その一方で，才 ゾンについては屋外で過ごす時間を一日のうち 1 時間と短時間に設 定したにもかかわらず屋外空気質の寄与が大きく，特に冬季におい ては屋外からの暴露の方が屋内からの暴露よりも大きいと算出され たケースが 3 分の 2 の割合にのぼった。

\section{文 献}

1) Harrison, R.M., Thornton, C.A., Lawrence, R.G., Mark, D., Kinnersley, R.P. and Ayres, J.G.: Personal exposure monitoring of particulate matter, nitrogen dioxide, and carbon monoxide, including susceptible groups. Occup. Environ. Med., 59, 671-679 (2002)

2) Thatcher, T.L. and Layton, D.W.: Deposition, resuspension, and penetration of particles within a residence. Atmos. Environ., 29, 


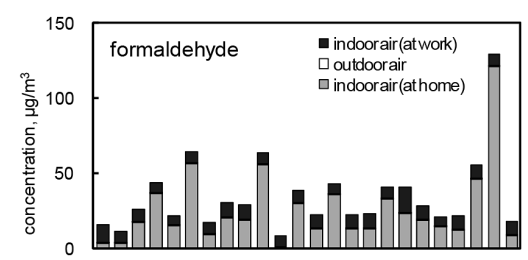

123456789101112131415161718192021222324

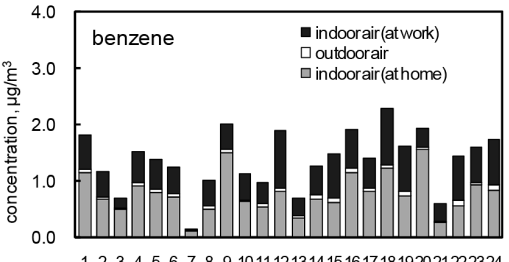

123456789101112131415161718192021222324

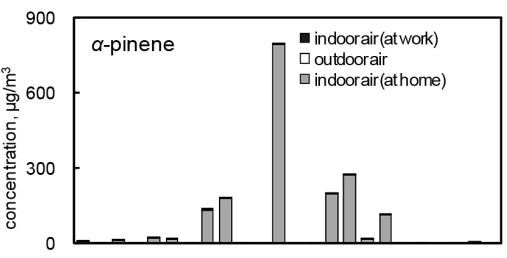

123456789101112131415161718192021222324

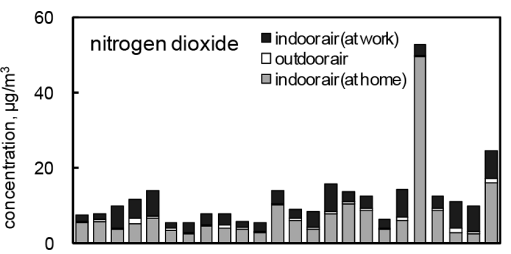

23456789101112131415161718192021222324

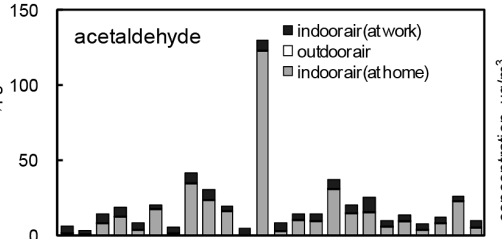

123456789101112131415161718192021222324

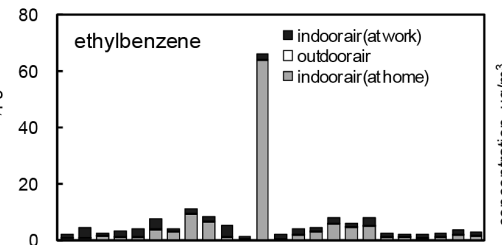

123456789101112131415161718192021222324

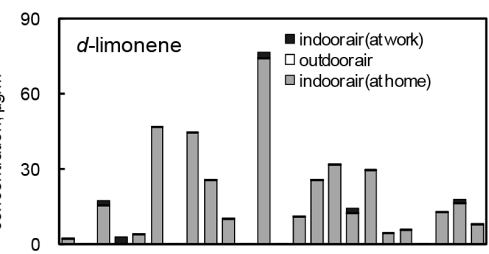

123456789101112131415161718192021222324

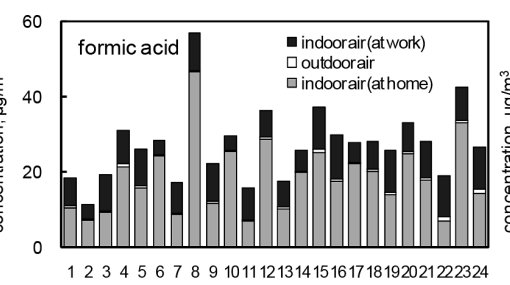

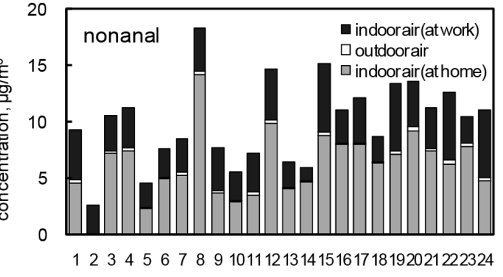
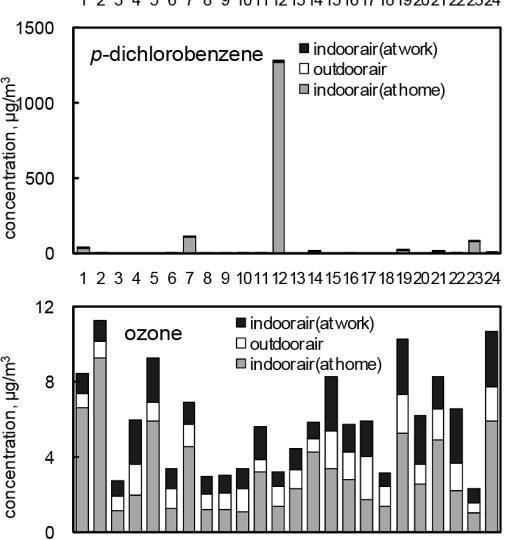

123456789101112131415161718192021222324

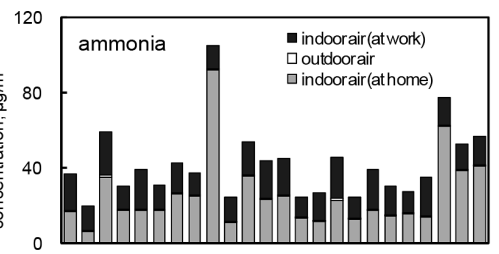

123456789101112131415161718192021222324

Fig. 7a Personal exposure throughout institutional building, residential house and outdoor air in summer

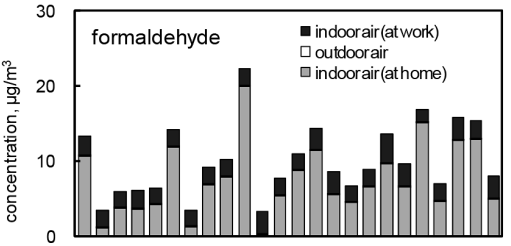

123456789101112131415161718192021222324

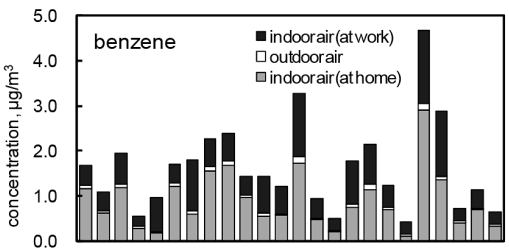

123456789101112131415161718192021222324

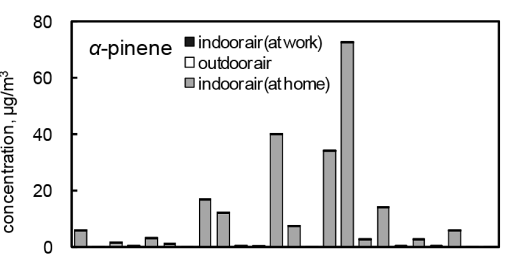

123456789101112131415161718192021222324

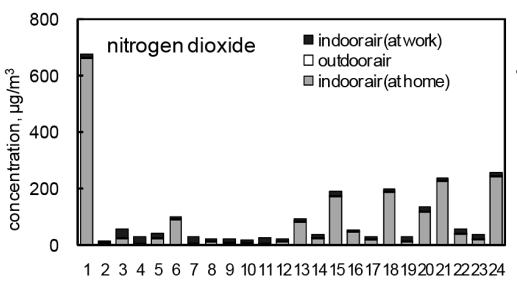

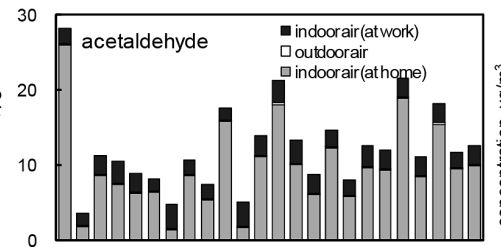

123456789101112131415161718192021222324
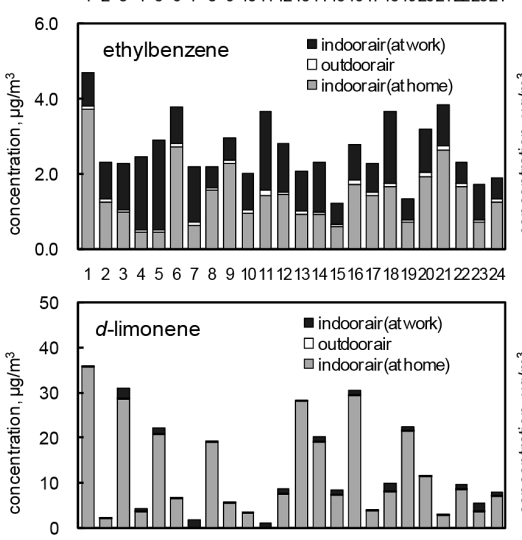

123456789101112131415161718192021222324

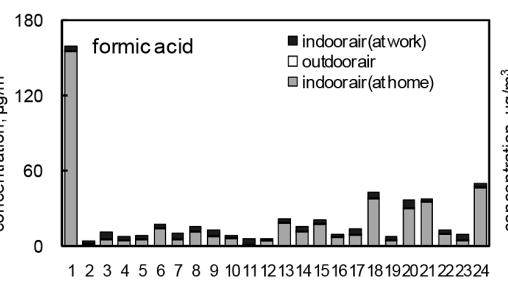

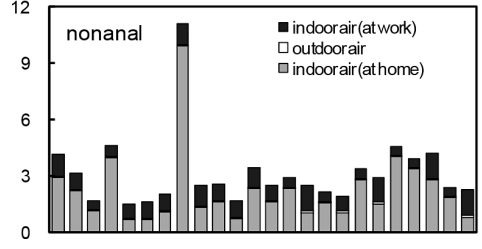

123456789101112131415161718192021222324
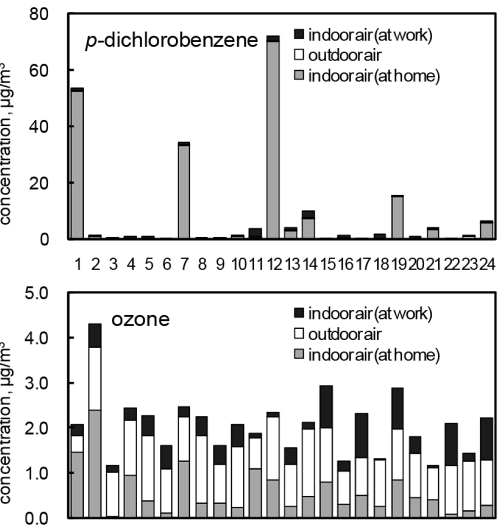

123456789101112131415161718192021222324

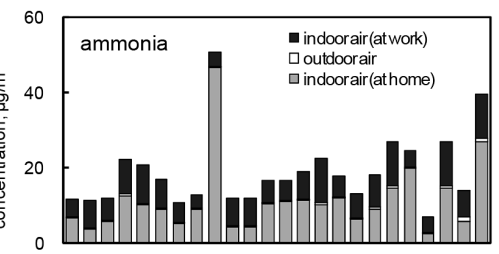

Fig. 7b Personal exposure throughout institutional building, residential house and outdoor air in winter 
1487-1497 (1995)

3）安藤正典：厚生科学研究「化学物質過敏症等室内空気中化学物 質に係わる疾病と総化学物質の存在量の検討と要因解明に関す る研究」平成14年度総括 ·分担研究報告書 (2003)

4) Uchiyama, S., Tomizawa, T., Tokoro, A., Aoki, M., Hishiki, M., Yamada, T., Tanaka, R., Sakamoto, H., Yoshida, T., Bekki, K., Inaba, Y., Nakagome, H. and Kunugita, N.: Gaseous chemical compounds in indoor and outdoor air of 602 houses throughout Japan in winter and summer. Environ. Res., 137, 364-372 (2015)

5）欅田尚樹：厚生労働科学研究「シックハウス症候群の発生予 防・症状軽減のための室内環境の実態調査と改善対策に関する 研究」平成23年度 - 平成25年度総合報告書 (2014)

6）田中礼子，山之内孝，加藤元規，内山茂久：新築公共建築物に おける室内空気質の濃度推移. 第24回環境化学討論会講演要旨 集, p-099 (2015)

7) Uchiyama, S., Asai, M. and Hasegawa, S.: A sensitive diffusion sampler for the determination of volatile organic compounds in ambient air. Atmos. Environ., 33, 1913-1920 (1999)

8) Uchiyama, S. and Hasegawa, S.: A reactive and sensitive diffusion sampler for the determination of aldehydes and ketones in ambient air. Atmos. Environ., 33, 1999-2005 (1999)

9) Uchiyama, S., Inaba, Y. and Kunugita, N.: A diffusive sampling device for simultaneous determination of ozone and carbonyls. Anal. Chim. Acta, 691, 119-124 (2011)

10) Yamada, T., Uchiyama, S., Inaba, Y., Kunugita, N., Nakagome, H. and Seto, H.: A diffusive sampling device for measurement of ammonia in air. Atmos. Environ., 54, 629-633 (2012)

11) Woolfenden, E.A. and McClenny, W.A.: Compendium of methods for the determination of toxic organic compounds in ambient air: Method TO-17, U. S. Environmental Protection Agency, Cincinnati, OH. 45268, EPA 625/R-96/010b (1997)

12) Uchiyama, S. and Otsubo, Y.: Simultaneous determination of ozone and carbonyls using trans-1,2-bis(4-pyridyl)ethylene as an ozone scrubber for 2,4-dinitrophenylhydrazine-impregnated silica cartridge. Anal. Chem., 80, 3285-3290 (2008)

13) Uchiyama, S., Naito, S., Matsumoto, M., Inaba, Y. and Kunugita,
N.: Improved Measurement of Ozone and Carbonyls Using a Dual-Bed Sampling Cartridge Containing trans-1,2-Bis(2-pyridyl) ethylene and 2,4-Dinitrophenylhydrazine-Impregnated Silica. Anal. Chem., 81, 6552-6557 (2009)

14) Arnts, R.R. and Tejada, S.B.: 2,4-Dinitrophenylhydrazine-coated silica gel cartridge method for determination of formaldehyde in air: identification of an ozone interference. Environ. Sci. Technol., 23, 1428-1430 (1989)

15) Smith, D.F., Kleindienst, T.E. and Hudgens, E.E.: Improved high-performance liquid chromatographic method for artifactfree measurements of aldehydes in the presence of ozone using 2,4-dinitrophenylhydrazine. J. Chromatogr. A, 483, 431-436 (1989)

16) Rodier, D.R., Nondek, L. and Birks, J.W.: Evaluation of ozone and water vapor interferences in the derivatization of atmospheric aldehydes with dansylhydrazine. Environ. Sci. Technol., 27, 28142820 (1993)

17) Uchiyama, S., Ando, M. and Aoyagi, S.: Isomerization of aldehyde-2,4-dinitrophenylhydrazone derivatives and validation of high-performance liquid chromatographic analysis. J. Chromatogr. A, 996, 95-102 (2003)

18) Uchiyama, S., Matsushima, E., Aoyagi, S. and Ando, M.: Measurement of acid-catalyzed isomerization of unsaturated aldehyde-2,4-dinitrophenylhydrazone derivatives by high-performance liquid chromatography analysis. Anal. Chim. Acta, 523, 157-163 (2004)

19) Uchiyama, S., Kaneko, T., Tokunaga, H., Ando, M. and Otsubo, Y.: Acid-catalyzed isomerization and decomposition of ketone-2,4dinitrophenylhydrazones. Anal. Chim. Acta, 605, 198-204 (2007)

20）瀬古繁喜, 大野定俊, 米澤敏男, 石黒武：コンクリートから発 生するアンモニアガスに関する研究. コンクリート工学会年次 論文報告集，973-978（1999）

21）松本利恵, 米持真一, 梅沢夏美, 坂本和彦 : 道路周辺のアンモ ニア・窒素酸化物濃度への自動車排出ガスの影響. 地球環境, 15, 103-110 (2010) 